\title{
Conformational Analysis of Protonated cyclo-[(S)-Phenylalanyl-(S)-Histidyl $]$ and its Complex with Benzaldehyde Within Metal-Organic Frameworks (MOFs)
}

\author{
Claudia F. Braga ${ }^{a}$ and Ricardo L. Longo ${ }^{*, b}$
}

\author{
${ }^{a}$ Departamento de Química, CCEN, Universidade Federal da Paraíba, 58036-300 João Pessoa-PB, Brazil \\ ${ }^{b}$ Departamento de Química Fundamental, Universidade Federal de Pernambuco, Cidade Universitária, \\ 50740-540 Recife-PE, Brazil
}

\begin{abstract}
A análise conformacional do dipeptídeo protonado ciclo-[( $S)$-fenilalanil- $(S)$-histidil], denominado ciclo- $\left[(S)\right.$-Phe- $(S)$-His- $\left.\mathrm{H}^{+}\right]$, dentro das cavidades de novos materiais porosos do tipo IRMOFs-phen (redes metal-orgânicas isoreticulares com pontes de 2,7-dicarboxilato fenantreno substituído) foi realizada com o método de química quântica AM1. Foram consideradas duas formas do ciclo-[(S)-Phe- $(S)$-His- $\left.\mathrm{H}^{+}\right]$, a saber, a forma ligada, em que o peptídeo está quimicamente ligado ao anel fenantreno, e a forma não-ligada, em que o peptídeo está livre dentro da cavidade. Os confôrmeros mais estáveis dentro da cavidade foram comparados àqueles encontrados em fase gás ou em água (modelados pelo método de solvente implícito SM5.4). As conformações preferenciais dentro da cavidade da IRMOF-phen são bem distintas das encontradas em fase gás ou em água. O ambiente químico da cavidade é também relevante, pois a substituição de um átomo de hidrogênio por $\mathrm{CH}_{3}$ (IRMOF-phen- $\mathrm{CH}_{3}$ ) ou $\mathrm{Br}$ (IRMOF-phen-Br) forneceu novas IRMOFs-phen que alteram significativamente as populações dos confôrmeros, assim como o sítio de adsorção do dipeptídeo. Estes resultados têm implicações importantes no controle da estéreo-seletividade de reações na presença de indutores quirais. De fato, esta é a primeira vez que uma conformação fechada para o ciclo- $\left[(S)\right.$-Phe- $(S)$-His- $\left.\mathrm{H}^{+}\right]$é determinada, assim como a obtenção de uma estrutura estável para o complexo ciclo-[(S)-Phe- $(S)$-His-H+ $\left.{ }^{+}\right]$-benzaldeído usando o método ONIOM(PBE1:AM1). Este complexo é compatível com a estrutura proposta para o estado de transição da hidrocianação do benzaldeído que explica a enantio-seletividade observada.
\end{abstract}

The conformational analysis of protonated cyclo-[(S)-phenylalanyl-(S)-histidyl], denoted as cyclo-

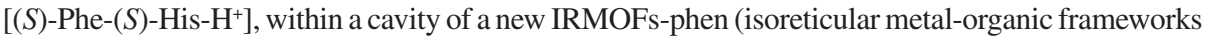
with a 2,7-dicarboxylate phenanthrene substituted bridges) porous material was performed with the AM1 quantum chemical method. Two forms of $c y c l o-\left[(S)-\mathrm{Phe}-(S)-\mathrm{His}-\mathrm{H}^{+}\right]$were considered: the bound-form, where the peptide is chemically linked to the phenanthrene moiety and the unbound-form where the peptide is free within the cavity. The most probable conformers of cyclo- $[(S)$-Phe- $(S)$-His$\left.\mathrm{H}^{+}\right]$within the cavity have been compared to the conformers in gas phase and in water, simulated by the implicit solvent SM5.4 model. The preferred conformations within the IRMOF-phen cavity are the $\left(\mathrm{g}^{-}, \mathrm{g}^{+}\right)$and $\left(\mathrm{t}, \mathrm{g}^{+}\right)$in contrast to the gas and aqueous phases. The environment within the cavity is also relevant, since the substitution of a hydrogen atom by $\mathrm{CH}_{3}\left(\mathrm{IRMOF}-\mathrm{phen}-\mathrm{CH}_{3}\right.$ ) or $\mathrm{Br}$ (IRMOF-phen-Br) lead to new IRMOFs-phen that changes drastically the conformer populations, as well as the adsorption site of the dipeptide. These results have important implications in controlling the stereoselectivity of reactions in the presence of chiral inductors. Indeed, this is the first time that a folded conformation of cyclo- $\left[(S)\right.$-Phe- $\left.(S)-\mathrm{His}_{-} \mathrm{H}^{+}\right]$was found, as well as an stable cyclo- $[(S)$-Phe$(S)$-His- $\left.\mathrm{H}^{+}\right]$-benzaldehyde complex was obtained using the ONIOM(PBE1:AM1) method. This complex is compatible with the proposed structure for the transition state of the hydrocyanation of benzaldehyde that explains the observed enantioselectivity.

Keywords: enantioselectivity conformation, quantum chemistry, confined species

\section{Introduction}

Chirality and more specifically the origin of the homochirality in our biota has been a life long interest of

*e-mail: longo@ufpe.br
Prof. Ricardo Ferreira. ${ }^{1}$ It is thus with great honor that we present this contribution showing that the selectivity of enantiomeric reactions can be increased within the confined spaces of cavities, such as, zeolites and isoreticular metalorganic frameworks. Indeed, porous solids are important for technological applications because they can interact 
with atoms, ions and molecules not only on their surfaces, but throughout the bulk of the material. ${ }^{2}$ Open metalorganic frameworks are widely regarded as promising materials for applications in catalysis, separations, gas storage and molecular recognition. Compared to conventionally used microporous inorganic materials such as zeolites, these metal-organic structures have the potential for more flexible rational design, by controlling the size and functionalization of the organic bridges ${ }^{3}$ as well as the architecture of the pores via secondary building units. ${ }^{4}$ The successful design of isoreticular metal-organic frameworks (IRMOFs) with rigid dicarboxylate rings connecting $\mathrm{Zn}_{4}\left(\mathrm{M}_{4}-\mathrm{O}\right)$ clusters has provided highly porous and thermally stable crystalline materials. ${ }^{3,5}$ In addition to their immediate application in gas storage, these materials can be used as confining systems for improving stereoselectivity in reactions with chiral inductors or auxiliaries as already explored for zeolites, ${ }^{6}$ as well as for enantioselective separation and catalysis. ${ }^{7}$

The cyclic dipeptide cyclo $[(S)$-phenylalanyl- $(S)$ histidyl] is an excellent catalyst for the hydrocyanation reaction of aldehydes with high enantioselectivity. ${ }^{8}$ Due to its importance in mimicking the role of enzymes active sites via its histidine-imidazole moiety this dipeptide was studied in detail by NMR and IR spectroscopy. ${ }^{9}$ This study aimed at the elucidation of the hydrocyanation reaction mechanism, ${ }^{9}$ where the conformation of the dipeptide and the interactions between the histidineimidazole moiety with the aldehyde and the cyanide are the most important aspects. The cyanide addition to carbonyl yielding cyanohydrin has a first order kinetics in the carbonyl compound and in the cyanide ion, and its mechanism has the nucleophilic attack of $\mathrm{CN}^{-}$to the carbonyl as the rate-determining step. ${ }^{10}$ However, in the presence of optically active amines this mechanism requires a minor modification to allow the formation of a hydrogen-bonded complex between the carbonyl oxygen and the proton of the amide cation. ${ }^{10}$ Thus, the protonated species was the chosen target for a conformational analysis (Figure 1).

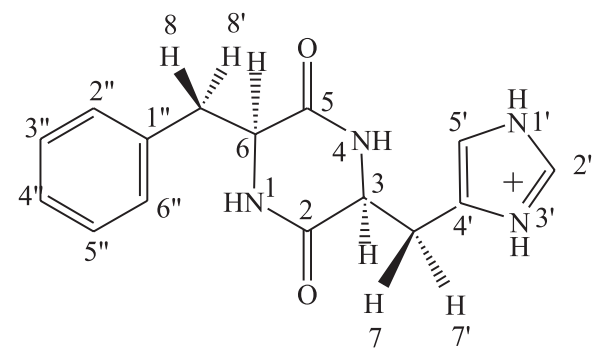

Figure 1. The structure and atomic numbering of protonated cyclo- $[(S)$ Phenylalanyl-(S)-histidyl], denoted as cyclo- $\left[(S)-\mathrm{Phe}-(S)-\mathrm{His}_{-} \mathrm{H}^{+}\right]$.
As part of the design of new organic bridges for IRMOFs, we propose the IRMOF-phen, with phen being the 2,7-dicarboxylate phenanthrene linker, substituted or not with $\mathrm{CH}_{3}$, $\mathrm{Br}$ or chiral group(s). Indeed, this IRMOFphen is very similar to the IRMOF- $-14,{ }^{3}$ which has the 2,7-dicarboxylate pyrene linker, but it is simpler from a computational point of view and has a larger cavity in order to fit the substrates as well as the nucleophile. We present the conformational analysis of protonated cyclo- $[(S)$ phenylalanyl-(S)-histidyl], denoted as cyclo-[(S)-Phe- $(S)$ His- $\mathrm{H}^{+}$], inside the IRMOF-phen cavity (unbound-form) and also of the peptide chemically linked to the phenanthrene moiety (bound-form), with the phenanthrene mimicking the phenyl ring of the phenylalanyl residue. As a result, the unbound-form of cyclo- $\left[(S)\right.$-Phe- $\left.(S)-\mathrm{His}_{-} \mathrm{H}^{+}\right]$leads to a chiral auxiliary within the confined space of the IRMOFphen cavities that can induce chirality in asymmetric reactions, while the new bound-form of IRMOF-phen has a chiral cavity. Indeed, the present results are the first ones to corroborate the folded conformation of the dipeptide suggested for its complexation with benzaldehyde. In addition, the hydrogen bonded and P-stacking complex between cyclo- $\left[(S)\right.$-Phe- $\left.(S)-\mathrm{His}_{-} \mathrm{H}^{+}\right]$and benzaldehyde has been obtained within the IRMOF-phen cavity, which suggests that hydrocyanation of this benzaldehyde should be highly enantioselective.

\section{Methodology and Computational Procedures}

The molecular structures of the IRMOF-phen with the bound and unbound forms of the peptide, the IRMOFphen-Br and the IRMOF-phen- $\mathrm{CH}_{3}$ with the free dipeptide within their cavities were obtained with the MOPAC2000 ${ }^{11}$ program using the AM1 (Austin Model 1) method. ${ }^{12}$ These structures were fully optimized with methyl groups saturating the dangling bonds of the cubic model. These optimized IRMOF capped- $\mathrm{CH}_{3}$ models were kept fixed when the conformational analysis the cyclo- $[(S)$-Phe- $(S)$ His- $\left.\mathrm{H}^{+}\right]$was performed without any constraints. Also, the molecular mechanics correction for the HNCO barrier was not used, since it does not make any difference in the conformational analysis. The aqueous medium was simulated with the SM5.4 solvation continuum model. ${ }^{13}$ All geometry optimizations were performed using the default program parameters and an energy gradient smaller than $4 \mathrm{~kJ} \mathrm{~mol}^{-1} \mathrm{~nm}^{-1}$.

The ONIOM(PBE1/6-31G(d,p):AM1) method m $^{14,15,12}$ has been used to obtain the molecular structure of the cyclo- $\left[(S)\right.$-Phe- $(S)$-His- $\left.\mathrm{H}^{+}\right]$-benzaldehyde complex within the IRMOF-phen cavity. The complex has been treated as 
<smiles></smiles>

Figure 2. Conformers $\left(\mathrm{g}^{-}, \mathrm{t}\right.$ and $\left.\mathrm{g}^{+}\right)$for the $\mathrm{C}_{\mathrm{A}}-\mathrm{C}_{\mathrm{B}}$ bond.<smiles>CC1C2CCC(C)(CC2N)C1C=O</smiles>

$\mathrm{t}$<smiles>CC12CCC(C(N)C1)C(C=O)C2</smiles>

$\mathrm{g}^{-}$ the high level layer (PBE1) and the IRMOF-phen as the low level one (AM1), which has been kept fixed during the geometry optimization.

\section{Results}

The AM1 method ${ }^{12}$ was used to calculate the standard enthalpy of formation $\left(\$_{\mathrm{f}} H^{0}\right)$ and the relative enthalpy $(\$ \$ H)$ at $298 \mathrm{~K}$ for the most probable conformers of the dipeptide cyclo- $\left[(S)\right.$-Phe- $\left.(S)-H i s-\mathrm{H}^{+}\right]$via a systematic and a stochastic conformational search procedure. The solvent effects (water) were considered in the calculations via the SM5.4 implicit hydration model. ${ }^{13}$ The systematic search involved the rotation around the $\mathrm{Cl}=\mathrm{N}(4)-\mathrm{C}(3)-\mathrm{C}(7)-\mathrm{C}\left(4^{\prime}\right)$ and $\mathrm{C}=\mathrm{N}(1)-\mathrm{C}(6)-\mathrm{C}(8)-\mathrm{C}\left(1^{\prime \prime}\right)$ dihedral angles (for the atomic numbering see Figure 1). It should be notice that only the conformation where $\mathrm{C}=\mathrm{C}(6)-\mathrm{C}(8)-\mathrm{C}(1 ")-\mathrm{C}\left(2^{\prime \prime}\right)$ $=270^{\circ}$ has been considered since the other non-equivalent conformation, $\mathrm{C} 3=90^{\circ}$, is very unstable. ${ }^{16}$ The notation $\mathrm{g}^{+}, \mathrm{g}^{-}$and $\mathrm{t}$ is related to conformers for the $\mathrm{C}_{\mathrm{A}}-\mathrm{C}_{\mathrm{B}}$ bonds and specify the relative position of the $\mathrm{NH}$ group at $\mathrm{C}_{\mathrm{A}}$ and the $\mathrm{C}$ (phenyl or imidazole) group at $\mathrm{C}_{\mathrm{B}}$ as illustrated in Figure 2.

The result of this systematic search yielded nine conformers that were energetically accessible. In addition, a stochastic search consisting of generating more than 40,000 conformations via the Monte Carlo method at 5000 $\mathrm{K}$ was performed. From this stochastic search, two new conformers were found and selected, since they presented compatible structures with the proposed transition state for the hydrocyanation. All the selected conformers are illustrated in Figure 3.

Considering that specific interactions are similar in all conformers, the SM5.4 approach can fairly represent the solvent effects on the conformational equilibrium. ${ }^{13}$ The enthalpy of formation and hydration of all nine conformers with their optimized $\mathrm{Cl}$ and $\mathrm{C} 2$ dihedral angles are presented in Table 1.

Also these conformers were confined in the IRMOFphen cavity (unbound-form) and had their geometry re-optimized, keeping the IRMOF-phen structure rigid. The cyclo- $\left[(S)-\mathrm{Phe}-(S)-\mathrm{His}-\mathrm{H}^{+}\right]$has also being chemically linked to the position 4 of the phenanthrene ring (boundform) in the IRMOF-phen, as illustrated in Figure 4, and the same conformations of the unbound-form were explored in this bound-form.
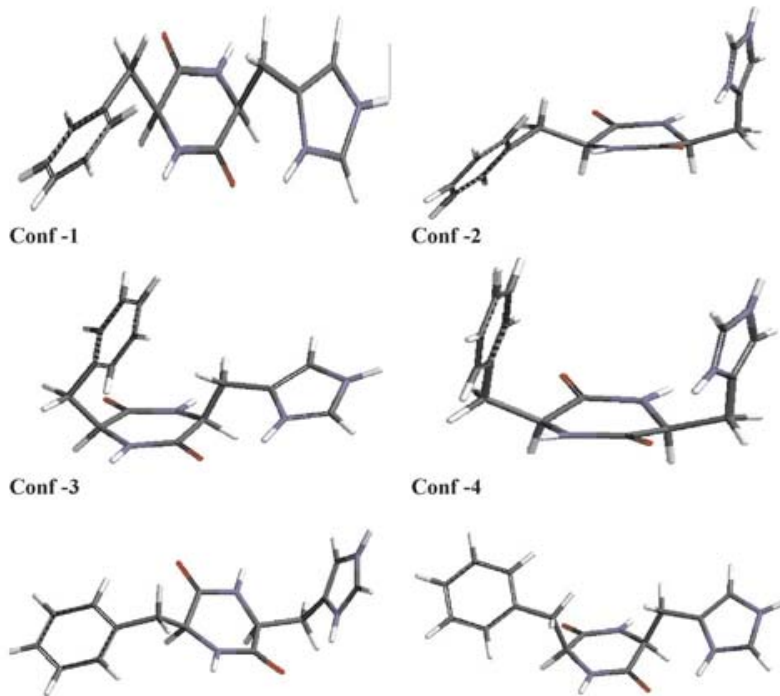

Conf -4

Conf -5

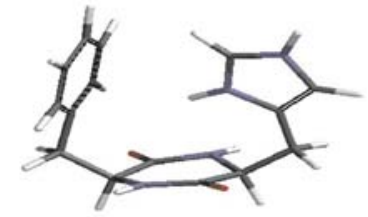

Conf -7

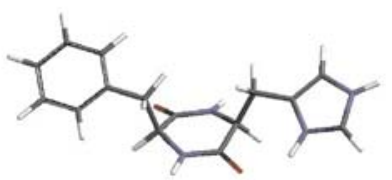

Conf -6

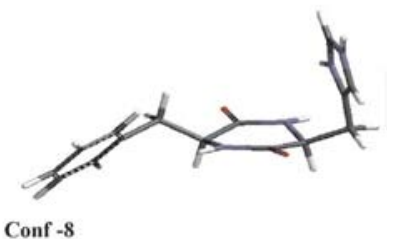

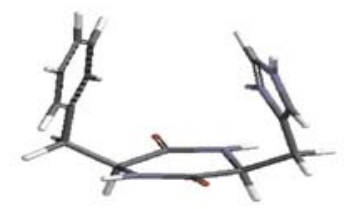

Conf -9

Figure 3. Conformers obtained by the systematic and stochastic searches and considered in conformational analysis in gas phase, aqueous solution and confined within the IRMOFs. The atoms are coded by the following colors: carbon (black), oxygen (red), nitrogen (blue) and hydrogen (white). 


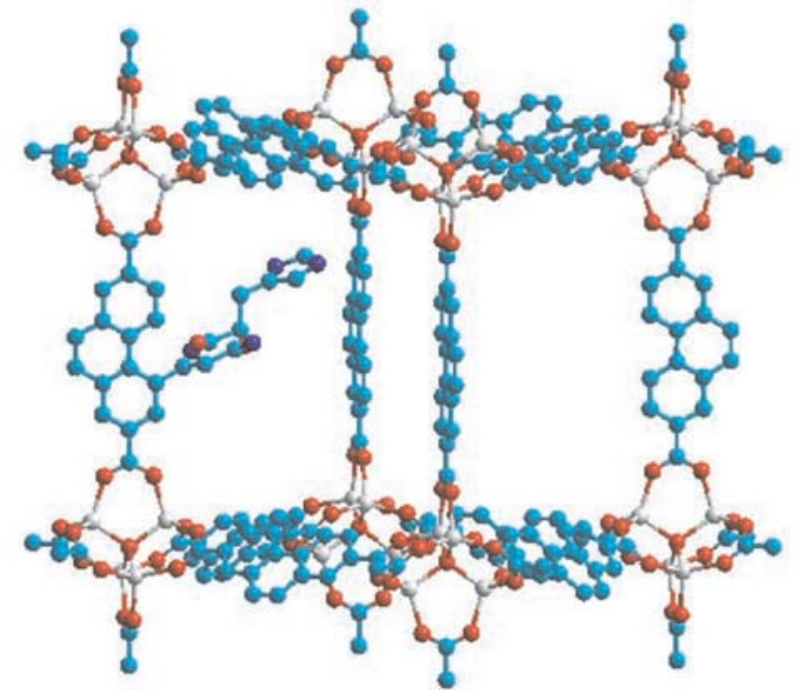

Figure 4. The structure of IRMOF-phen with the bound-form of cyclo$\left[(S)\right.$-Phe- $(S)-$ His- $\left.\mathrm{H}^{+}\right]$. The hydrogen atoms were omitted. The atoms are coded by the following colors: carbon (cyan), oxygen (red), nitrogen (blue) and zinc (gray).
The relative enthalpies of the most stable conformers for the unbound- and bound-forms are presented in Table 2 with their respective $\mathrm{C} 1$ and $\mathrm{C} 2$ dihedral angles.

The same analysis was performed for the unbound-form of the cyclo- $\left[(S)\right.$-Phe- $(S)$-His- $\left.\mathrm{H}^{+}\right]$within the cavity of the IRMOF-phen- $\mathrm{CH}_{3}$ (IRMOF with a 2,7-dicarboxylate1-methyl-phenanthrene bridge) and IRMOF-phen-Br (IRMOF with a 2,7-dicarboxylate-9-bromo-phenanthrene bridge). The results for the relative enthalpies and optimized dihedral angles the most stable conformers are presented in Table 3.

\section{Discussion}

Due to some known shortcomings of the AM1 method $^{17}$ for performing conformational analysis, its choice deserves some comments. Firstly, several molecular mechanics force-field were tested, but none have performed satisfactory in reproducing a stable structure for the model

Table 1. Optimized dihedral angles ( $\mathrm{n}$ ), enthalpies (in $\mathrm{kJ} \mathrm{mol}^{-1}$ ) of hydration, $\$_{\mathrm{h}} H$, of formation in gas phase, $\$ \mathrm{f}(\mathrm{g})$, and of formation in aqueous solution, $\$_{\mathrm{f}} H(a q)$, for the stochastic conformational search of $c y c l o-\left[(S)\right.$-Phe- $\left.(S)-\mathrm{His}_{-} \mathrm{H}^{+}\right]$. The numbers in parenthesis are relative enthalpies (in $\mathrm{kJ}$ mol $\left.{ }^{-1}\right)$

\begin{tabular}{|c|c|c|c|c|c|}
\hline Conformer $^{\mathrm{a}}$ & $\mathrm{Cl}$ & $\mathrm{C} 2$ & $\$_{h} H$ & $\$_{f} H(g)$ & $\$ \$_{f} H(a q)$ \\
\hline Conf-1 & -139.9 & -61.5 & -243.5 & $587.9(0.00)$ & $344.4(0.00)$ \\
\hline Conf-2 & 60.8 & -60.5 & -238.1 & $590.7(2.80)$ & $352.6(8.21)$ \\
\hline Conf-3 & -143.1 & 63.3 & -243.5 & $591.9(4.01)$ & $348.4(4.07)$ \\
\hline Conf-4 & 60.2 & 51.5 & -238.5 & $593.0(5.13)$ & $354.5(10.1)$ \\
\hline Conf-5 & 60.5 & -123.8 & -241.4 & $601.6(13.7)$ & $360.2(15.8)$ \\
\hline Conf-6 & -142.9 & -150.0 & -253.1 & $602.7(14.8)$ & $349.6(5.23)$ \\
\hline Conf-7 & 65.7 & 57.6 & -227.6 & 604.7 (16.8) & $377.1(32.7)$ \\
\hline Conf-8 & 63.1 & -61.3 & -243.5 & 604.8 (16.9) & $361.3(16.9)$ \\
\hline Conf-9 & -122.6 & 58.4 & -237.2 & $607.1(19.2)$ & 369.9 \\
\hline
\end{tabular}

${ }^{a}$ See Figure 1 for the definition of dihedrals angles, $\mathrm{Cl}$ and $\mathrm{C}$.

Table 2. Relative enthalpy of formation, $\$ \$ H\left(\mathrm{~kJ} \mathrm{~mol}^{-1}\right)$, and optimized dihedral angles (n) for the most probable conformers of $c y c l o-\left[(S)\right.$-Phe- $(S)$-His- $\left.\mathrm{H}^{+}\right]$ within the IRMOF-phen cavity (unbound-form) and chemically linked to the phenanthrene ring of IRMOF-phen

\begin{tabular}{|c|c|c|c|c|c|c|}
\hline \multirow{2}{*}{$\begin{array}{l}\text { Conformer }^{\mathrm{a}} \\
\text { (His,Phe) }\end{array}$} & \multicolumn{3}{|c|}{ Bound-form } & \multicolumn{3}{|c|}{ Unbound-form } \\
\hline & $\$ \$ \$_{f} H$ & $\mathrm{Cl}$ & $\mathrm{C} 2$ & $\$ \$ H$ & $\mathrm{Cl}$ & $\mathrm{C} 2$ \\
\hline$\overline{\left(g^{-}, t\right)}$ & 172.6 & -62.5 & -159.8 & 17.8 & -138.3 & -115.4 \\
\hline$(\mathrm{t}, \mathrm{t})$ & 146.9 & 120.6 & -154.7 & 16.9 & -154.6 & 177.6 \\
\hline$\left(\mathrm{g}^{-}, \mathrm{g}^{+}\right)$ & 32.5 & 73.5 & -71.7 & 0.0 & -142.2 & 62.6 \\
\hline$\left(\mathrm{g}^{+}, \mathrm{g}^{-}\right)$ & 121.2 & 67.0 & -74.4 & 21.4 & 56.4 & 75.9 \\
\hline$\left(\mathrm{t}, \mathrm{g}^{-}\right)$ & 117.9 & -144.6 & -71.8 & 20.5 & -141.6 & -58.8 \\
\hline$\left(\mathrm{g}^{-}, \mathrm{g}^{-}\right)$ & 5.8 & -64.3 & -72.6 & 38.9 & -80.9 & -37.8 \\
\hline$\left(g^{+}, t\right)$ & 132.3 & 72.1 & -154.6 & 424.7 & 16.6 & -77.8 \\
\hline$\left(\mathrm{t}, \mathrm{g}^{+}\right)$ & 5.3 & 139.1 & 61.6 & 0.7 & -143.4 & -21.3 \\
\hline$\left(\mathrm{g}^{+}, \mathrm{g}^{+}\right)$ & 5.3 & 138.2 & 60.8 & 24.4 & 54.8 & 42.8 \\
\hline$\left(-140, \mathrm{~g}^{-}\right)$ & 138.9 & -144.1 & -72.5 & 50.3 & -144.6 & -60.9 \\
\hline$\left(\mathrm{g}^{+}, 50\right)$ & 0.0 & 61.5 & -54.8 & 25.3 & 59.5 & 48.5 \\
\hline
\end{tabular}

${ }^{\mathrm{a}}$ See Figure 1 for the definition of the dihedrals angles $\mathrm{Cl}$ and $\mathrm{C}$. 
Table 3. Relative enthalpy of formation, $\$ \$ H\left(\mathrm{~kJ} \mathrm{~mol}^{-1}\right)$, and optimized dihedral angles $(\mathrm{n})$ for the most probable conformers of $c y c l o-\left[(S)-\mathrm{Phe}-(S)-\mathrm{His}-\mathrm{H}^{+}\right]$ within the IRMOF-phen- $\mathrm{CH}_{3}$ and IRMOF-phen-Br cavity

\begin{tabular}{|c|c|c|c|c|c|c|}
\hline \multirow{2}{*}{$\begin{array}{l}\text { Conformer } \\
\text { (His,Phe) }\end{array}$} & \multicolumn{3}{|c|}{ IRMOF-phen- $\mathrm{CH}_{3}$} & \multicolumn{3}{|c|}{ IRMOF-phen-Br } \\
\hline & $\$ \${ }_{\mathrm{f}} H$ & $\mathrm{Cl}$ & $\mathrm{C} 2$ & $\$ \$$ & $\mathrm{Cl}$ & $\mathrm{C} 2$ \\
\hline$\left(\mathrm{g}^{-}, \mathrm{t}\right)$ & 14.0 & -113.6 & 139.3 & 0.0 & -139.2 & -125.0 \\
\hline$(\mathrm{t}, \mathrm{t})$ & 38.1 & -154.5 & -176.8 & 857.8 & -138.5 & 159.3 \\
\hline$\left(\mathrm{g}^{-}, \mathrm{g}^{+}\right)$ & 41.6 & -70.5 & 49.1 & 823.7 & -153.4 & 62.7 \\
\hline$\left(\mathrm{g}^{+}, \mathrm{g}^{-}\right)$ & 7.3 & -54.4 & 58.8 & 989.7 & 58.4 & -54.9 \\
\hline$\left(\mathrm{t}, \mathrm{g}^{-}\right)$ & 11.0 & -139.8 & -45.1 & 867.6 & -139.7 & -56.1 \\
\hline$\left(\mathrm{g}^{-}, \mathrm{g}^{-}\right)$ & 12.0 & -138.6 & -56.2 & 875.0 & -37.9 & -82.9 \\
\hline$\left(g^{+}, t\right)$ & 55.2 & -156.2 & 40.7 & 882.6 & 48.4 & -169.4 \\
\hline$\left(\mathrm{t}, \mathrm{g}^{+}\right)$ & 5.8 & -139.5 & -50.9 & 824.9 & -47.8 & -140.8 \\
\hline$\left(\mathrm{g}^{+}, \mathrm{g}^{+}\right)$ & 69.5 & 55.4 & 66.1 & 855.2 & 66.1 & 58.3 \\
\hline$\left(-140, \mathrm{~g}^{-}\right)$ & 0.0 & -139.9 & -61.8 & 750.8 & -144.6 & -60.9 \\
\hline$\left(\mathrm{g}^{+}, 50\right)$ & 57.7 & 60.2 & 52.1 & 735.9 & 61.9 & 49.3 \\
\hline
\end{tabular}

${ }^{a}$ See Figure 1 for the definition of the dihedrals angles $\mathrm{Cl}$ and $\mathrm{C}$.

IRMOF-1 (IRMOF with a 1,4-dicarboxylate benzene bridge), probably due to the unusual bonding in the $\mathrm{Zn}_{4}(\mathrm{M}-\mathrm{O})$ cluster. Secondly, due to the size of the system, for instance, the model system IRMOF-phen-Br + cyclo$\left[(S)\right.$-Phe- $\left.(S)-\mathrm{His}^{-} \mathrm{H}^{+}\right]$has the following empirical formula: $\mathrm{C}_{255} \mathrm{H}_{174} \mathrm{O}_{106} \mathrm{~N}_{4} \mathrm{Zn}_{32} \mathrm{Br}_{12}$, so that ab initio ${ }^{18}$ or DFT ${ }^{19}$ methods are impractical to perform extensive conformational searches. However, since the AM1 method has yielded very good results for reproducing the structure of the IRMOF- $1^{20}$ and we are interested in comparing trends and relative sequences of conformations, we believe that the main conclusions about the confining effects of the IRMOF cavities are reliable. In addition, previous conformation analysis of the neutral cyclo- $(S)$-Phe- $(S)$-His by semiempirical methods have yielded results compatible with NMR measurements in benzene and DMSO solutions. ${ }^{9}$

Regarding the proposed new IRMOF-phen it is simpler, from a computational point of view, than the IRMOF- $14,{ }^{3}$ which has a 2,7-dicarboxylate pyrene (PDC) bridge. However, despite the phen bridge being less symmetric than the PDC bridge, it is very likely that the phen would form an isoreticular structure. In addition, cavity size and free volume of the IRMOF-phen should be slightly larger than the IRMOF-14, so that it could accommodate the protonated dipeptide cyclo- $\left[(S)\right.$-Phe- $(S)$-His- $\left.\mathrm{H}^{+}\right]$and aldehydes, like benzaldehyde, and $\mathrm{HCN}$ within the cavity, in order to promote the stereoselective hydrocyanation reaction. ${ }^{21}$

Also, the modeling of the crystalline IRMOF deserves some comments. It was simulated by one unit cell capped with methyl groups, which enclosed one cavity, as shown in Figure 4. This model has been successfully tested and validated by comparing with crystallographic results, which provided very good agreement when the AM1 method was used. ${ }^{20}$ In addition to this structural agreement, the vibrational spectrum of the $\left[\mathrm{Zn}_{4}(\mathrm{M}-\mathrm{O})\left(\mathrm{CH}_{3} \mathrm{OO}\right)_{6}\right]$ complex has been adequately simulated ${ }^{20}$ by the AM1 method. Since the model simulates the crystal by a cluster-type approach, it seems reasonable to keep the cluster structure rigid at its optimized structure upon loading with dipeptide and other molecules, because in the case of the crystal it would be expected that the lattice would impose this rigidity for this kind of loading.

From Table 1 it can be observed that the stability of the cyclo- $\left[(S)\right.$-Phe- $(S)$-His- $\left.\mathrm{H}^{+}\right]$conformers in gas phase has the following sequence: $\left(\mathrm{t}, \mathrm{g}^{-}\right)>\left(\mathrm{g}^{+}, \mathrm{g}^{-}\right) \mathrm{y}\left(\mathrm{t}, \mathrm{g}^{+}\right)>\left(\mathrm{g}^{+}, 50^{\circ}\right)$, whereas in solution: $\left(\mathrm{t}, \mathrm{g}^{-}\right)>\left(\mathrm{t}, \mathrm{g}^{+}\right)>\left(\mathrm{g}^{+}, \mathrm{g}^{-}\right)>\left(\mathrm{g}^{+}, 50 \mathrm{n}\right)$. In addition to some reordering of the stability sequence of the conformers, the solvent effects have strong influence in the energy differences, causing an increase from 19.2 to $32.7 \mathrm{~kJ} \mathrm{~mol}^{-1}$ in the energy difference between the most stable and unstable conformers in gas phase and solution, respectively. In gas phase there is a clear separation between Conf-4 and Conf-5 (8.6 kJ mol $\left.{ }^{-1}\right)$, which is lost in solution. Note also the strong solvent effects in the energy of Conf-6, which becomes the third most stable conformer. Also, pairs of conformers (Conf- 2 and Conf- 8 ) and (Conf- 4 and Conf-7) have very similar dihedral angles ( $\mathrm{Cl}$ and $\mathrm{C}$ ), but their energies are quite different due to the orientation of the histidyl ring. Conformers Conf- 4 and Conf- 9 have the most probable structure for the proposed structure for the transition state of the cyanide addition to the carbonyl of benzaldehyde. The hydrogen bonded complex would be formed between the carbonyl of benzaldehyde and either hydrogen in the HN(1) or HN(4) groups, and an additional stabilization could be provided by the $\mathrm{P}$-stacking interaction between the phenyl rings of the phenylalanyl residue and the benzaldehyde molecule, as well as with the P-electrons of the histidyl residue. 
The confining effects of the IRMOF cavity on the conformation of cyclo- $\left[(S)-\mathrm{Phe}-(S)-\mathrm{His}-\mathrm{H}^{+}\right]$can be observed in Table 2, which clearly shows that the boundform has a very distinct conformational behavior when compared to the unbound-form. Namely, the bound-form has essentially two conformers $(61.5,-54.8)$ and (139.0, 61.0) for the optimized dihedrals angles, which are not the same for the unbound-form, that has the $(-142.2,62.6)$ and $(-143.4,-21.3)$ thermally accessible conformers at room temperature. In addition, for the unbound-form, the chemical environment of the cavity induces significant changes in the conformational behavior of the dipeptide as can be ascertain by comparing Tables 2 and 3. Upon substitution by $-\mathrm{CH}_{3}$ and $-\mathrm{Br}$ groups, the conformer populations change from $(-142.2,62.6)$ and $(-143.4,21.3)$ for IRMOF-phen to $(-138.9,-61.8)$ and $(-139.5,-50.9)$ for IRMOF-phen- $\mathrm{CH}_{3}$ and to $(-139.2,-125.0)$ for IRMOFphen- $\mathrm{Br}$, where in this last environment there is only one accessible conformation.

Some representative conformers of cyclo- $[(S)$-Phe- $(S)$ His- $\left.\mathrm{H}^{+}\right]$within the IRMOF-phen, IRMOF-phen- $\mathrm{CH}_{3}$ and IRMOF-phen-Br are presented in Figures 5 e 6.

In addition to the effects in the conformer populations, the substitution of $\mathrm{H}$ by $\mathrm{CH}_{3}$ and $\mathrm{Br}$ in the IRMOF-phen

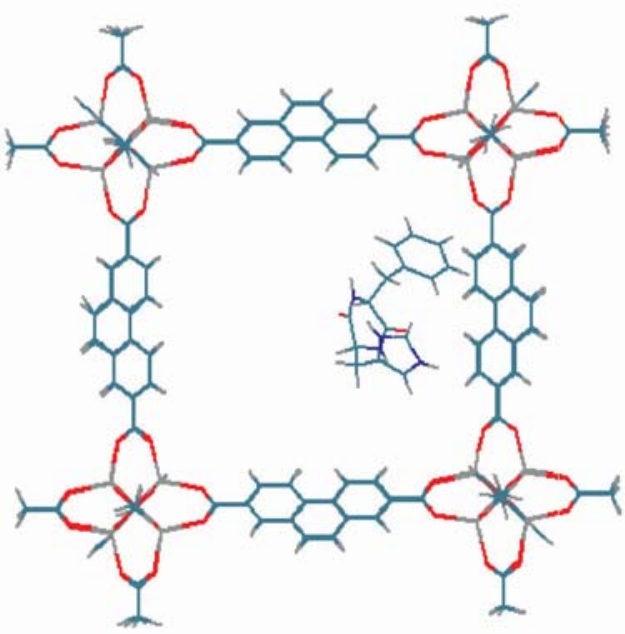

conformer $\left(\mathrm{g}^{+}, 50^{\circ}\right)$

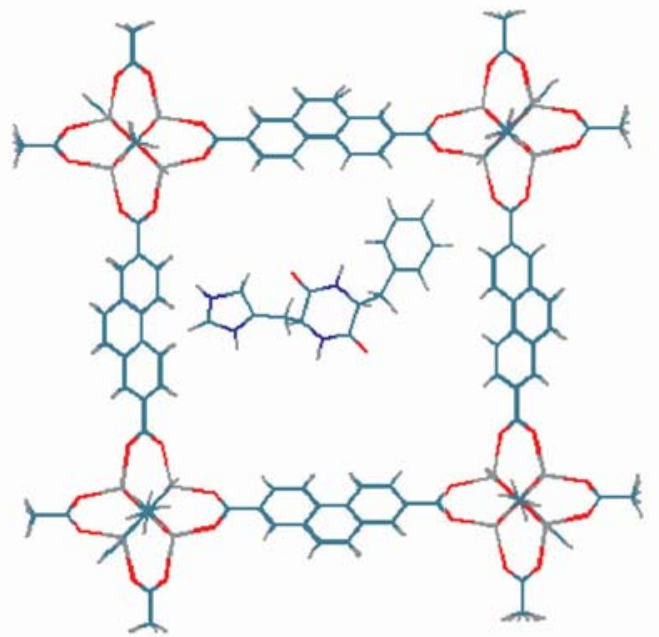

conformer $\left(-140, \mathrm{~g}^{-}\right)$

Figure 5. The molecular structures of some representative conformers within the IRMOF-phen.

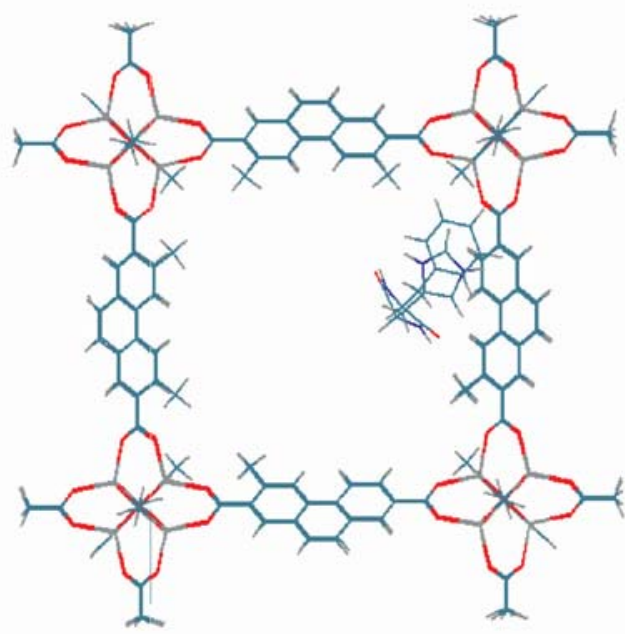

IRMOF-phen- $\mathrm{CH}_{3}$

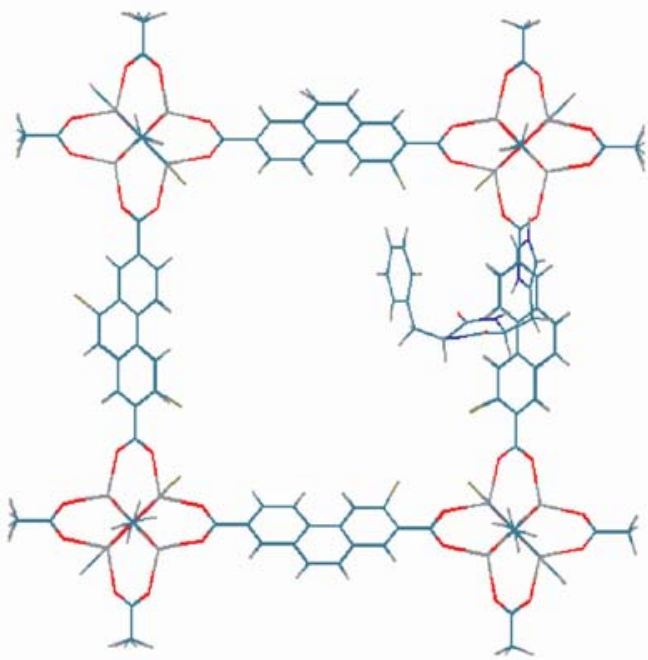

IRMOF-phen-Br

Figure 6. The molecular structures of the $\left(\mathrm{g}^{+}, 50\right)$ conformer within the IRMOF-phen- $\mathrm{CH}_{3}$ and IRMOF-phen-Br. 

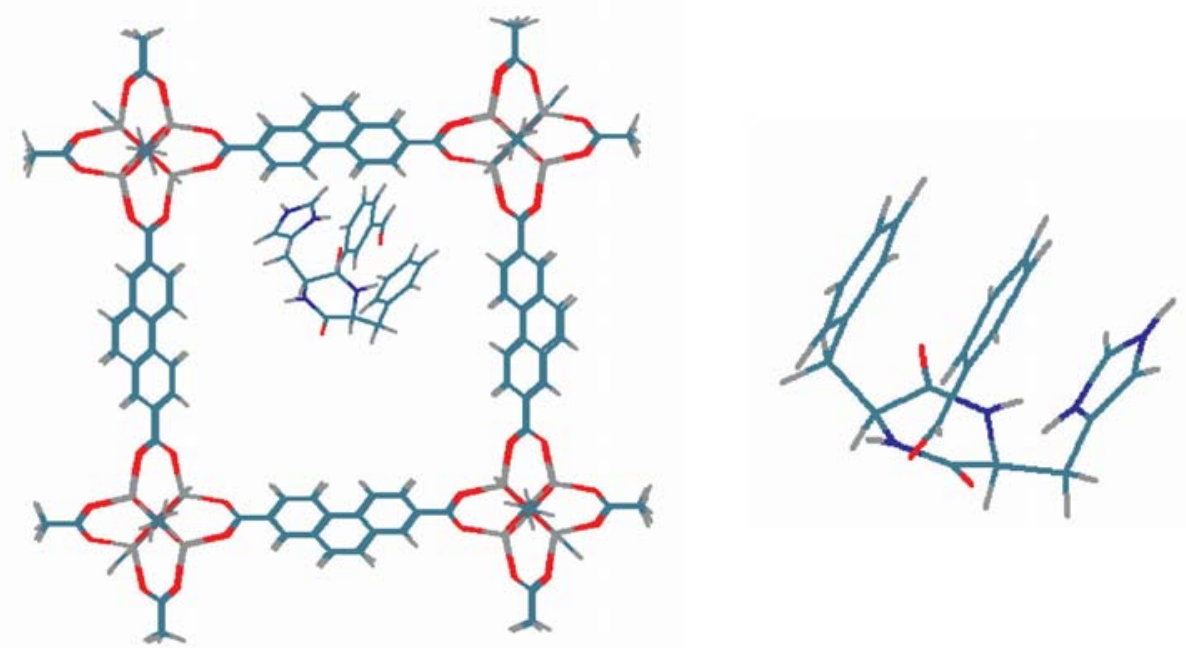

Figure 7. The ONIOM(PBE1:AM1) calculated molecular structure of the $c y c l o-\left[(S)-\mathrm{Phe}-(S)-\mathrm{His}-\mathrm{H}^{+}\right]$-benzaldehyde complex within the IRMOF-phen. On the right, an amplified view of the complex.

affects significantly the relative position of the cyclo$\left[(S)\right.$-Phe- $\left.(S)-\mathrm{His}_{-} \mathrm{H}^{+}\right]$within the cavity. Despite the initial relative position of the dipeptide being the center of the cavity, during its geometry optimization it migrates to the edge of the IRMOF-phen- $\mathrm{CH}_{3}$ and IRMOF-phen-Br in order to perform a hydrogen bond between the carboxylic oxygen and the hydrogen at the protonated histidyl ring. Thus the adsorption of the dipeptide changes remarkably with cavity environment.

These results show the importance of confined spaces in selecting a specific conformation as well as the adsorption site, thus determining the selectivity of reactions catalyzed by the dipeptide. Regarding the hydrocyanation of benzaldehyde, a dipeptide-benzaldehyde complex has been found which could explain the observed enantioselectivity in solution and also indicates that this selectivity can be increased within the cavity of IRMOF-phen. The molecular structure of the complex is illustrated in Figure 7.

The use of the ONIOM(PBE1:AM1) method is quite important, since the PBE1 hybrid functional ${ }^{15}$ improves the description of hydrogen bonds and intermolecular interactions quite significantly. ${ }^{22}$ Other functionals as well as $\mathrm{HF} / 6-31 \mathrm{G}(\mathrm{d}, \mathrm{p})$ and AM1 methods were inadequate to study the cyclo- $\left[(S)\right.$-Phe- $(S)$-His- $\left.\mathrm{H}^{+}\right]$-benzaldehyde complex either in gas phase or within the IRMOF-phen. In the ONIOM(PBE1:AM1) calculated structure the complex is stabilized by a hydrogen bond between the $\mathrm{HN}(1)$ and the carbonyl oxygen as well as P-stacking-type interactions between the aromatic rings. In addition, considering the positive charge on the histidyl ring, the anion $\mathrm{CN}^{-}$should approach the carbonyl group preferably from the side of this ring, thus inducing enantioselectivity as observed in solution. However, in solution, this selectivity should be lower since the conformer $\left(\mathrm{g}^{+}, 50\right)$ or conf- 9 should have a very small population, whereas within the IRMOF-phen it has a significantly population. Indeed, for the boundform of the cyclo- $\left[(S)-\mathrm{Phe}-(S)-\mathrm{His}-\mathrm{H}^{+}\right]$to the IRMOFphen, this conformer is the most stable one, and thus the enantioselectivity predicted within this material should be even higher. Studies are underway to determine the structure of the peptide-benzaldehyde complex in this new IRMOF as well as the transition states related to the addition of cyanide into the carbonyl.

\section{Conclusions}

The confining space of the IRMOFs cavity has significant effects upon the thermal conformational populations of the dipeptide cyclo- $\left[(S)\right.$-Phe- $\left.(S)-\mathrm{His}_{-} \mathrm{H}^{+}\right]$, when compared to conformers in gas or aqueous phases. In addition, the chemical environment of the cavity can influence these populations, where an $-\mathrm{CH}_{3}$ substituent in the phenanthrene ring of the IRMOF-phen leads to several distinct thermally accessible conformers, whereas an $-\mathrm{Br}$ substituent leads essentially to one only conformer, at room temperature. Also, these substituents affect remarkably the adsorption sites of the dipeptide. We have successfully determined a stable structure of the cyclo- $[(S)$-Phe- $(S)$-His$\mathrm{H}^{+}$-benzaldehyde complex within the IRMOF-phen. As a result, the cavities of the IRMOFs can not only change the conformer populations, but also stabilize intermediate structures and complexes by a proper designed environment of the cavity, thus improving the enatioselectivity of organocatalyzed reactions. 


\section{Acknowledgment}

We wish to thank Prof. Ricardo Ferreira for his constant encouragement to study chiral systems and to acknowledge the following Brazilian Agencies: CNPq, CAPES, FACEPE, FAPESQ-PB, CT-Petro/CNPq, FINEP, PADCT, PRONEX and RENAMI for their partial financial support.

\section{References}

1. Lins, R. D.; Soares, T. A.; Ferreira, R.; Z. Naturforsch. 1996, 51c, 70; Soares, T. A.; Lins, R. D.; Longo, R.; Garratt, R.; Ferreira, R.; Z. Naturforsch. 1997, 52c, 89; Ferreira, R. C.; J. Mol. Struct. (THEOCHEM) 2002, 580, 1; Lins, R. D.; Ferreira,

R. C.; Quim. Nova 2006, 29, 997.

2. Davis, M. E.; Nature 2002, 417, 813.

3. Li, H.; Eddaoudi, M.; O'Keefee, M.; Yaghi, O. M.; Nature 1999, 402, 276; Eddaoudi, M.; Kim, J.; Rosi, N.; Vodak, D.; Wachter, J.; O'Keeffe, M.; O. M. Yaghi; Science 2002, 295, 469.

4. Eddaoudi, M.; Moler, D. B.; Li, H.; Chen, B.; Reineke, T. M.; O'Keeffe, M.; Yaghi, O. M.; Acc. Chem. Res. 2001, 34, 319.

5. Yaghi, O. M.; O'Keefee, M.; Ockwig, N. W.; Chae, H. K.; Eddaoudi, M.; Kim, J.; Nature 2003, 423, 705.

6. Ramamurthy, V.; Eaton, D. F.; Caspar, J. V.; Acc. Chem. Res. 1992, 25, 299.

7. Seo, J. S.; Whang, D.; Lee, H.; Jun, S. I.; Oh, J., Jeon, Y. J.; Kim, K.; Nature 2000, 404, 982.

8. Tanaka, K.; Mori, A.; Inoue, S.; J. Org. Chem. 1990, 55, 181.

9. Callant, D.; Coussens, B.; Maten, T. v.d.; de Vries, J. G.; de Vries, N. K.; Tetrahedron Asym. 1992, 3, 401.
10. Lowry, T. H.; Richardson, K. S; Mechanism and Theory in Organic Chemistry, $3^{\text {rd }}$ ed., HarperCollins Publishers: New York, 1987, pp. 680-683.

11. Stewart, J. J. P.; MOPAC2000; Fujitsu Limited, Tokyo, Japan, 1999.

12. Dewar, M. J. S.; Zoebisch, E. G.; Healy, E. F.; Stewart; J. J. P.; J. Am. Chem. Soc. 1985, 107, 3902.

13. Cramer, C. J.; Trular, D. G.; J. Am. Chem. Soc. 1991, 11, 8305.

14. Maseras, F.; Morokuma, K.; J. Comp. Chem. 1995, 16, 1170; Humbel, S.; Sieber S.; Morokuma, K.; J. Chem. Phys. 1996, 105, 1959; Matsubara, T.; Sieber, S.; Morokuma, K.; Int. J. Quantum Chem. 1996, 60, 1101.

15. Perdew, J.; Burke, K.; Ernzerhof, M.; Phys. Rev. Lett. 1996, 77, 3865.

16. Sheinblatt, M.; Andorn, M.; Rudi, A.; Int. J. Peptide Protein Res. 1988, 31, 373.

17. Dewar, M. J. S.; Jie, C. X.; Yu, J. G.; Tetrahedron 1993, 49, 7393; Scheiner, S.; Rev. Comp. Chem. 1991, 2, 165.

18. Hehre, W. J.; Radom, L.; Schleyer, P. V. R.; Pople, J. A.; Ab Initio Molecular Orbital Theory, John Wiley \& Sons: New York, 1986.

19. Koch, W; Holthausen, M. C.; A Chemist's Guide to Density Functional Theory, $2^{\text {nd }}$ ed, Wiley-VCH: Weinheim, 2001.

20. Braga, C. F.; Longo, R. L.; J. Mol. Struct. (THEOCHEM) 2005, $716,33$.

21. Oku J.; J. Chem. Soc., Chem. Commun. 1981, 5, 229.

22. Ireta, J.; Neugbauer, J.; Schefler, M.; J. Phys. Chem. A 2004, 108,5692 . 